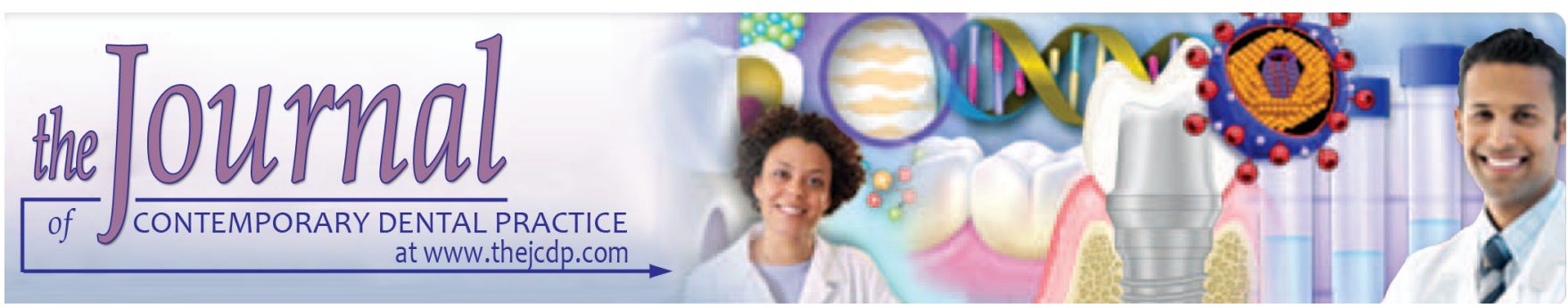

\title{
Pulpotomy Medicaments used in Deciduous Dentition: An Update
}

\author{
Yousef H Al-Dlaigan
}

\begin{abstract}
The aim of this paper was to review the history and the scientific literature published on pulpotomy medicaments and to present the findings of these studies. The review showed that pulpotomy of primary teeth has been treated with many different techniques and medicaments, that some of these approaches are controversial and that their results have presented variables of success rates in term of clinical, radiographic and histologic observation. It is important that all clinicians, particularly for pediatric dentists, be up to date with the recent trends in this area of dental treatment for children.
\end{abstract}

Keywords: Calcium hydroxide, Deciduous dentition, Formocresol, Mineral trioxide aggregate, Pulpotomy.

How to cite this article: Al-Dlaigan YH. Pulpotomy Medicaments used in Deciduous Dentition: An Update. J Contemp Dent Pract 2015;16(6):486-503.

Source of support: Nil

Conflict of interest: None

\section{INTRODUCTION}

Vital pulpotomy is the clinical treatment of choice for primary teeth with exposed pulp. Pulpotomy can be defined as the surgical removal or amputation of the coronal pulp of the vital tooth. This step is generally followed by the placement of a particular medicament over the intact stump to fix, mummify or stimulate repair of the remaining radicular pulp. ${ }^{1}$

Department of Pediatric Dentistry and Orthodontics, Division of Pediatric Dentistry, College of Dentistry, King Saud University Riyadh, Saudi Arabia

Corresponding Author: Yousef HAl-Dlaigan, Program Director Postgraduate Pediatric Dentistry; Associate Professor Department of Pediatric Dentistry and Orthodontics, Division of Pediatric Dentistry, College of Dentistry, King Saud University PO BOX 60169, Riyadh 11545, Saudi Arabia, Phone: 0114677228, e-mail: yaldlaigan@hotmail.com
There have been three common medicaments used for pulpotomy in primary teeth: formocresol, calcium hydroxide $\left[\mathrm{Ca}(\mathrm{OH})_{2}\right]$ and glutaraldehyde; however, other medicaments have been investigated for pulpotomy procedures, including electrosurgery and laser, ferric sulfate freeze-dried bone, bone morphogenetic protein, osteogenic protein-1, the novel anti-inflammatory agent tetrandrine, collagen, feracrylum, glass ionomer, mineral trioxide aggregate (MTA), lyophilized freezedried platelet-derived enamel matrix derivative, sodium hypochlorite, Portland cement, nanohydroxyapatite, calcium-enriched mixture, calcium phosphate cement, and Allium sativum oil.

The clinical successes of these medicaments have differed from each other in biological compatibility, healing capabilities, mutagenicity, cytotoxicity, histological response and carcinogenic potential. Therefore, the aim of this study was to review the history and the scientific literature published on pulpotomy medicaments and to present the findings of these studies.

\section{PULP THERAPY}

Pulp therapy was perhaps first described in 1756 by Philip Pfaff, who performed pulp capping by attempting to cover exposed pulp with a small piece of gold carefully adapted to the base of the cavity. Leonard Koecker, in $1826,{ }^{2}$ cauterized the uncovered portion of the pulp using a red hot iron wire, subsequently covering the contacted tissue with a piece of lead foil.

In 1899, 'Gysi's triopaste' was introduced as the first compound to combine formaldehyde and creosote to fix pulp under permanently sterile conditions. ${ }^{3}$ The use of various materials and drugs in close contact with pulp tissue has been reported in the literature. Some materials have been reported to promote healing of the pulp, including the following: asbestos, plaster of Paris, powdered ivory, tissue paper, Canada balsam, asbestos 
sponge, vulcanized rubber, court plaster, cork, quill, gutta percha, oiled silk, gall nuts, beeswax, pulverized glass, collodion, boracic acid, iodoform powder, iodoformagen, formaldehyde, lacto-phosphate of lime, borax, zinc oxychloride cement, zinc oxide, zinc oxide eugenol, zinc oxide with thymol and zinc phosphate cement. ${ }^{4}$ All of these materials were used clinically before 1950, and a great variety of commercial preparations with known and unknown formulas have been used, with various degrees of success.

\section{FORMOCRESOL}

Formocresol was introduced in 1904 by Buckley ${ }^{5}$ for the treatment of the putrescent pulp in animal teeth. Buckley's original formula consisted of concentrated formalin $53 \mathrm{gm}$, cresol $35 \mathrm{gm}$, glycerol $7 \mathrm{gm}$ and water $5 \mathrm{gm}$. A commercial formula was later introduced by Buckley that consisted of 19\% formaldehyde, 35\% cresol and glycerin in distilled water.

In 1923 and again in 1930, Sweet ${ }^{6,7}$ suggested formocresol for the treatment of primary teeth with vital pulp exposed by caries. Hess ${ }^{8}$ reported negative results in a bacterial analysis of 62 pulp samples mummified with formaldehyde paste. However, Foster ${ }^{9}$ later described successful treatment using formocresol and paste. Strange ${ }^{10}$ reported clinical success for pulpotomies ranging from 75 to $95 \%$ over a 7 to 36 months time frame.

In 1956, Nacht ${ }^{11}$ undertook using formaldehyde paste a radiographic evaluation of 467 primary teeth from the office files of the Vancouver Pedodontic Study Club. By analyzing radiographs, Nacht found that the teeth were maintained in good clinical condition for approximately 2 years. He also reported evidence of resorption and a lack of clinical symptoms over a 5 years period. Wong ${ }^{12}$ studied the effects of a paraformaldehyde paste on the amputated pulp and periapical tissues of primary and permanent teeth in rhesus monkeys. The length of treatment was from 9 to 84 days in primary teeth and 37 to 48 days in permanent teeth. The author found in both dentitions similar inflammatory reactions and degenerative changes in the bone. He also reported evidence of lymphocytic infiltration into the underlying dental sacs of the permanent teeth.

Massler and Mansukhani ${ }^{13}$ studied the histologic effects of formocresol on the amputated pulp of 205 rat molars and 43 primary and permanent human teeth. They described, in the rat molars, the defensive reaction as fibrous encapsulation of the inflammatory cells, followed by calcification of the capsule and reparative dentin formation; also, the apposition of new dentin matrix bridging was reported. However, their results in the pulp of human teeth after 7 and 14 days showed three distinctive zones: a broad acidophillic zone (fixation), a broad pale-staining zone (atrophy) and a broad zone of inflammatory cells (inflammation). They also reported that no secondary or reparative dentin formation was observed in any of the specimens. Additionally, at 60 days, only a strand of eosinophilic fibrous tissue remained at the exposure site.

Emmerson et $\mathrm{al}^{14}$ reported a histologic study of 20 carious and noncarious exposed primary teeth. They used formocresol on cotton pledgets over amputated pulp stumps for periods of time of 5 minutes to 3 days. Immediately, below the amputation area, there was a homogeneous yellow-stained area, and below that area was a normal-appearing fixed zone of pulp tissue. Below the fixed zone, there was evidence of degenerated odontoblasts and linear pulp calcification. The authors also reported that, throughout the pulp, there was an absence of inflammatory cells, with no evidence of resorption or metaplastic changes.

In 1961, Dietz ${ }^{15}$ studied the histological effects of formocresol on elastic changes to normal primary pulp tissue in noncarious primary cuspids. The teeth were extracted at intervals ranging from 24 hours to 16 weeks. He reported that pulpal tissue seemed to wall off the zone of surface necrosis produced by formocresol, forming an acellular, collagenous-like band. The band was seen after 24 hours, but the odontoblastic layer was present adjacent to the collagenous band in the earlier stages. The band eventually disappeared by 16 weeks. No reparative dentin formation was found at any time. Dietz reported that the pulp tissue seemed to produce a new pulpal network of young proliferating fibroblasts. Doyle ${ }^{16}$ used formocresol to treat infected pulp and reported superficial debris with occasional dentin chips at the amputation site, followed by a subjacent layer of compressed, darkly stained tissue with a fibrous appearance. He also reported that the formocresol technique was $71 \%$ successful by histological evaluation. In another study, Doyle et $\mathrm{al}^{17}$ described the histologic findings in human primary molars as being characterized by the lack of an inflammatory response, absence of calcification at the wound site and formation of a typical surface layer of compressed acidophilic tissue, which was fibrous in appearance.

Spedding ${ }^{18}$ conducted a histological study in rhesus monkeys of 20 primary teeth treated with formocresol for 5 minutes. The pulp was observed after periods of 17 to 286 days in contact with zinc oxide-formocresol paste. All 20 of the teeth showed evidence of vital pulp tissue. Some of the pulp showed leukocytic infiltration and osteodentin formation in the apical regions. $\operatorname{Redig}^{19}$ compared a one-appointment technique and a two-appointment pulpotomy technique using Buckley's formocresol. The 
study was performed on carious primary molars in children whose ages ranged from 3 years and 6 months old to 8 years and 11 months old. Twenty children were included as subjects. The results showed no significant differences between the procedures.

Straffon and $\operatorname{Han}^{20}$ evaluated the effect of a 1:5 dilution of formocresol on hamster connective tissue cells, and they found that formocresol at that concentration did not interfere with prolonged recovery of connective tissue and, in fact, seemed to suppress the initial inflammatory response significantly. Morawa et $\mathrm{al}^{21}$ performed 125 pulpotomies on primary molars of 83 patients using a 1:5 concentration of Buckley's formula. This concentration was prepared by mixing three parts of glycerin with one part of concentrated formocresol and one part water. They reported clinical success equal to that obtained with the use of full-strength formocresol. Fuks and Bimstein ${ }^{22}$ observed 77 primary teeth clinically and radiographically of children treated with pulpotomies using a 1:5 dilution of formocresol. The rate of clinical success was $94.3 \%$ in that study. They reported that the 1:5 dilution of formocresol was an effective alternate medicament for primary vital pulpotomy procedures in children. A summary of the success rates of the studies ${ }^{10,17,21-61}$ using formocresol as a pulpotomy medicament is provided in Table 1.

\section{ZINC OXIDE-EUGENOL}

The most common technique used for pulpotomy procedures utilizes formocresol as the primary agent for pulp treatment. Then, zinc oxide-eugenol cement is placed as a material over the formocresolized radicular pulp stumps. This technique is believed to produce non-vital pulp by mummification. The pulp response depends on the length of time for which the formocresol is in contact with pulp tissue. ${ }^{14}$

Berger $^{25}$ compared the effects of a formocresol medication to the effects of zinc oxide-eugenol paste when placed on pulp tissue. Pulpotomies were performed on 52 teeth, of which 35 received a formocresol treatment for 5 minutes, followed by zinc-oxide eugenol. In another 17 teeth, a zinc oxide-eugenol dressing was placed over the pulp tissue. This histologic evaluation began at 3 weeks and concluded at 38 weeks. The author reported that the use of formocresol on vital pulp tissue produced necrotic changes and pulp tissue replacement by granulation tissue, which changed to osteodentin with eventual narrowing of the lumen of the canals. He also reported that, radiographically, the formocresol-treated teeth were judged to be $97 \%$ successful, while the zinc oxide-eugenol group was $58 \%$ successful. Beaver et $\mathrm{al}^{3}$ reported the histological effects of zinc oxide-eugenol cement on formocresol-treated pulp from 60 primary molars with near or actual carious pulp exposure. The study was conducted in two groups: one using regular zinc oxide-eugenol paste and the other using the addition of one drop of formocresol to the zinc oxide-eugenol mix. The follow-ups of the study occurred at 1,2, and 3 months. Following the pulpotomy procedures, the authors concluded that the responses of the remaining pulpal tissue following formocresol treatment consisted of reactions only to zinc oxide-eugenol cement. Additionally, the formocresol pulpotomy response was due to eventual endogenous root canal filling. Boller ${ }^{62}$ studied the reaction of the dental pulp tissue to either a formocresol-type or to a zinc oxide-type medicament using a one-appointment pulpotomy technique in 88 primary human molar teeth aged 4 to 9 years old. Fifty-seven teeth were available for evaluation. The author used the same technique on 48 non-carious primary molars of monkeys. The results of his study were evaluated over an 18 months period. All of the teeth remained clinically asymptomatic. The remaining teeth did not show the development of periapical or interradicular bone rarefaction throughout the experimental period. However, the teeth treated with zinc oxide showed variable responses of acute or chronic inflammation, internal resorption and pulpal fibrosis. A similar variety of histologic responses were observed in human pulp treated with formocresol. Garcia-Godoy ${ }^{63}$ compared zinc oxide-eugenol and polycarboxylate cements in formocresol pulpotomies. He reported mild inflammation in the area of amputation following formocresol pulpotomy, while moderate to severe inflammation was observed with the use of zinc oxide-eugenol. However, when the results of zinc oxideeugenol were compared with those of the polycarboxylate cement group, it appeared that most of the inflammation was due to the eugenol.

Until recently, from clinical, radiological and biological viewpoints, formocresol as a tissue fixative was the most widely accepted medicament for pulpotomy. In recent years, the use of formocresol pulpotomy began to be questioned because of the possible toxicity of formocresol, due to both systemic effects and potential harm to the permanent teeth. Loos et $\mathrm{l}^{64}$ studied the biological effects of formocresol. In experimental animals, a 1:5 dilution of full-strength Buckley's formula was effective in causing cytostasis, which produced irreversible damage to some of the connective tissue cells. They also reported that some of the clinical and histological problems reported in the past when using formocresol could be eliminated using a 1:5 concentration of the original formula. Myers et $\mathrm{al}^{65}$ performed $\mathrm{C}^{14}$ formaldehyde pulpotomies on rhesus monkeys. They demonstrated that the drug was 
Table 1: The percentage of successes for the studies using formocresol as a pulpotomy medicament

\begin{tabular}{|c|c|c|c|c|c|}
\hline \multirow[b]{2}{*}{ Authors } & \multirow[b]{2}{*}{ Number of teeth } & \multirow[b]{2}{*}{ Time of observation (months) } & \multicolumn{3}{|c|}{ Percentage of success } \\
\hline & & & $C$ & $R$ & $H$ \\
\hline \multirow[t]{3}{*}{ Doyl et al $(1662)^{17}$} & 16 & $5-18$ & 100 & - & - \\
\hline & 28 & $1-18$ & - & 93 & - \\
\hline & 17 & $0-12$ & - & - & 76 \\
\hline Sweet $(1963)^{23}$ & 561 & 18 & 97 & - & - \\
\hline Law and Lewis $(1964)^{24}$ & 324 & 48 & 90 & 90 & - \\
\hline Berger $(1965)^{25}$ & 31 & $0-9$ & 100 & 97 & 82 \\
\hline Morawa et al $(1974)^{21}$ & 125 & $6-60$ & 98 & 98 & - \\
\hline $\begin{array}{l}\text { Rolling and Thylstrup } \\
(1975)^{26}\end{array}$ & 98 & $3-36$ & 70 & 70 & - \\
\hline Magnusson $(1978)^{27}$ & 84 & $6-36$ & 100 & - & 0 \\
\hline Mejare $(1979)^{28}$ & 81 & 30 & 55 & 55 & - \\
\hline Magnusson $(1980)^{29}$ & 84 & $1-36$ & - & - & 0 \\
\hline $\begin{array}{l}\text { Fuks and Bimstein } \\
(1981)^{22}\end{array}$ & 77 & $4-36$ & 94 & - & - \\
\hline Garcia-Godoy $(1984)^{30}$ & 45 & $6-18$ & 96 & 96 & - \\
\hline Hicks et al $(1986)^{31}$ & 164 & $24-87$ & - & 94 & - \\
\hline Prakash et al $(1989)^{32}$ & 30 & $1-6$ & 90 & 90 & - \\
\hline Fei et al $(1991)^{33}$ & 26 & 12 & 96.3 & 81 & - \\
\hline Fuks et al $(1996)^{34}$ & 31 & 35 & 83.8 & 73 & - \\
\hline Papagiannoulis $(2002)^{35}$ & 58 & 36 & 97.3 & 78.3 & - \\
\hline $\begin{array}{l}\text { Ibricevic and Al-Jame } \\
(2003)^{36}\end{array}$ & 78 & $42-48$ & 97.5 & 91.7 & - \\
\hline Agamy et al $(2004)^{37}$ & 18 & 12 & 90 & 90 & - \\
\hline Jabbarifar et al $(2004)^{38}$ & 29 & 12 & 91 & 91 & - \\
\hline Huth et al $(2005)^{39}$ & 44 & 24 & 96 & 93.4 & - \\
\hline Markovic et al $(2005)^{40}$ & 30 & 18 & 90.9 & 84.8 & - \\
\hline Farsi et al (2005) ${ }^{41}$ & 35 & 24 & 97.2 & 86.8 & - \\
\hline Holan et al $(2005)^{42}$ & 24 & 74 & 83 & 83 & - \\
\hline Naik and Hedge $(2005)^{43}$ & 23 & 6 & 100 & 100 & - \\
\hline Aeinehchi et al $(2007)^{44}$ & 57 & 6 & 100 & 90.5 & - \\
\hline $\begin{array}{l}\text { Subramaniam et al } \\
(2009)^{45}\end{array}$ & 20 & 24 & 100 & 85 & - \\
\hline Zealand et al $(2010)^{46}$ & 100 & 6 & 97 & 86 & - \\
\hline $\begin{array}{l}\text { Ansari and Ranjpour } \\
(2010)^{47}\end{array}$ & 14 & 24 & 100 & 90 & - \\
\hline $\begin{array}{l}\text { Hugar and Deshpande } \\
(2010)^{48}\end{array}$ & 30 & 36 & 100 & 96.7 & - \\
\hline Gisoure $(2011)^{49}$ & 24 & 9 & 100 & 87.5 & - \\
\hline Erdem et al $(2011)^{50}$ & 18 & 24 & 72 & 72 & - \\
\hline Godhi et al $(2011)^{51}$ & 25 & 12 & 100 & 88 & - \\
\hline $\begin{array}{l}\text { Srinivasan and Jayanthi } \\
(2011)^{52}\end{array}$ & 42 & 12 & 91.3 & 78.2 & - \\
\hline Sushynski et al $(2012)^{53}$ & 65 & 24 & 98 & 76 & - \\
\hline Airen et al $(2012)^{54}$ & 30 & 24 & 85 & 54.3 & - \\
\hline Huth et al $(2012)^{55}$ & 72 & 36 & 92 & - & - \\
\hline Mettlach et al $(2013)^{56}$ & 131 & 42 & 99 & 79 & - \\
\hline Havale et al (2013) & 23 & 12 & 76.7 & 56.7 & - \\
\hline Jayam et al $(2014)^{58}$ & 42 & 24 & 90.4 & 90.4 & - \\
\hline Yildiz and Tosun $(2014)^{59}$ & 35 & 30 & 100 & 95.2 & - \\
\hline $\begin{array}{l}\text { Durmus and Tanboga } \\
(2014)^{60}\end{array}$ & 40 & 12 & 97 & 87 & - \\
\hline Olatosi et al $(2015)^{61}$ & 25 & 12 & 81 & 81 & - \\
\hline
\end{tabular}

C: Clinically; R: Radiographically; H: Histologically 
present in the periodontal ligament, and in the systemic bone, absorption was also noted. Pashley et $\mathrm{al}^{66}$ studied the distribution of $\mathrm{C}^{14}$ formaldehyde in 16 formocresol pulpotomies performed in two dogs. $\mathrm{C}^{14}$ formaldehyde was found in body fluids. However, the quantities were small, and the most systemic absorption was in the liver.

If a large number of pulpotomies were completed in the same animal or human, the possibility of systemic toxicity caused by formocresol is of concern. This outcome is more likely in children treated under general anesthesia, and the possibility of systemic toxicity has been reported to be much higher in such cases. Other studies ${ }^{27,67}$ have reported certain side effects from the use of formocresol in clinical and histological studies, as well as several combinations of irregular pulp responses. These responses have included normal pulp, fibrosis, necrosis, hyperemia, inflammation, internal resorption, granulation tissue and osteodentin. In addition, Pruhs et $\mathrm{al}^{68}$ reported the presence of enamel hypoplasia on the underlying developing premolars of pulpotomized teeth treated with formocresol. In contrast, Rolling and Poulsen ${ }^{69}$ evaluated the possible relationship between formocresol treatment of a primary tooth and enamel changes in the permanent successor. They found no relationship between formocresol pulpotomy of primary teeth and enamel defects in their permanent successors. However, they did report an increased prevalence of premolars erupting into a rotated position following exfoliation of a pulpotomized primary molar. Research conducted in animals revealed that formaldehyde demonstrated an insignificant level of antigenicity. ${ }^{70}$

Van Mullem et $\mathrm{al}^{71}$ reported that, in a study in guinea pigs using formocresol as a root canal disinfectant, the drug demonstrated allergic potential. Presentation of both formaldehyde and cresol in only one tooth per animal appeared to result in (weak) allergic potential, even when enhanced by Freud's adjuvant. Rolling and Thulin $^{72}$ reported on 128 children, ages 5 to 14 years old, with formocresol-pulpotomized teeth. The children were tested for allergic sensitivity to formaldehyde, eugenol and cresol using the patch test. The number of teeth that were treated varied with each child and ranged from one to six; the time between the pulpotomy and the patch test varied from 2 months to 6 years. None of the children had a positive patch test for formaldehyde, eugenol or cresol. Information regarding the mutagenic and carcinogenic potential of formaldehyde-containing products, the cytotoxic effects of formocresol and possible diffusion of these substances into the surrounding and systemic tissue has also been reported. ${ }^{73}$ Formocresol does not promote healing of the pulp; it is locally toxic and has been shown to be potentially damaging to systemic tissues. ${ }^{70}$

\section{CALCIUM HYDROXIDE}

Calcium hydroxide was introduced in combination with other salts as a pulp-capping agent called calxyl. Additionally, in 1938, Teuscher and Zander ${ }^{74}$ reported the presence of a complete dentinal bridge and healthy radicular pulps that had been directly pulp capped with $\mathrm{Ca}(\mathrm{OH})_{2}$ dressings. Zander ${ }^{75}$ reported a histological study using $\mathrm{Ca}(\mathrm{OH})_{2}$ (calxyl) in the pulp capping of primary and permanent teeth. This study showed the formation of an amorphous calcified layer on the cut pulp surface. This layer formed the matrix for regular dentin formation, resulting in a bridge covering the exposed pulp tissue. Glass and Zander ${ }^{4}$ reported firmly established $\mathrm{Ca}(\mathrm{OH})_{2}$ paste as the pulp capping agent of choice in a histological study conducted in permanent teeth, and they found rapid healing when exposed pulp was capped with $\mathrm{Ca}(\mathrm{OH})_{2}$. A clinical and radiographic study by $\mathrm{Via}^{76}$ reported on 103 pulpotomized deciduous molars treated with a paste made of $\mathrm{Ca}(\mathrm{OH})_{2}$ and sterile water and followed for an average period of 24.9 months. The treatment failed in $68.19 \%$ of the teeth studied due to internal resorption; however, the study was only a clinical radiographic evaluation. Doyle et $\mathrm{al}^{17}$ compared the histological, radiographic and clinical success of formocresol and $\mathrm{Ca}(\mathrm{OH})_{2}$ in pulpotomies of human teeth. Their results showed 76 to $100 \%$ success in the formocresol group, whereas in the $\mathrm{Ca}(\mathrm{OH})_{2}$ group, the success rate was from 50 to $71 \%$. Magnusson ${ }^{77}$ reported a success rate of only $2.5 \%$ in a histologic study of 130 pulpotomized primary mandibular molars using $\mathrm{Ca}(\mathrm{OH})_{2}$ paste. In addition, he reported internal resorption in $80 \%$ of primary teeth capped with $\mathrm{Ca}(\mathrm{OH})_{2}$ paste (calxyl).

Schroder and Granath ${ }^{78}$ longitudinally studied pulpotomies of eight primary second molars of children treated with a paste mixture of $\mathrm{Ca}(\mathrm{OH})_{2}$ and a physiologic sodium chloride solution. Extraction of these teeth was completed at different time points of between 11 and 38 months due to extensive internal resorption. The authors concluded that extra-pulpal blood clots caused chronic inflammation, which might have resulted in internal dentin resorption. Schroder ${ }^{79}$ also reported the effects of extrapulpal blood clots on the healing of 18 lower bicuspid human teeth. After 2 weeks in two teeth and 1 month in the remaining teeth, she reported that an extrapulpal blood clot between the wound surface and the sterile $\mathrm{Ca}(\mathrm{OH})_{2}$ paste tended to impair healing under otherwise optimal conditions.

Schroder and Granath ${ }^{80}$ reported that, in a histological study of $\mathrm{Ca}(\mathrm{OH})_{2}$, a three-layered zone of necrosis 1 to $15 \mathrm{~mm}$ thick was a consistent finding following the use of $\mathrm{Ca}(\mathrm{OH})_{2}$ paste. However, in another histological study, 
Schroder and Granath ${ }^{81}$ reported on two human bicuspids that received $\mathrm{Ca}(\mathrm{OH})_{2}$ as a pulpotomy dressing. After 3 months, scanning electron microscopy demonstrated hard-tissue formation. The two layers of calcified tissue consisted of a coronal portion with a bone-like appearance and cell inclusions and a pulpal portion resembling dentin. Tronstad and Mjor ${ }^{82}$ reported on a histological study of monkey teeth with inflamed pulp exposed and capped with $\mathrm{Ca}(\mathrm{OH})_{2}$. The results were successful using $\mathrm{Ca}(\mathrm{OH})_{2}$ as a wound dressing in endodontics because it was considered to be biologically suitable, thus contributing to wound healing. However, the treatment was not as effective as on the inflamed pulp tissues of monkey teeth.

Schröder ${ }^{83}$ reported on 37 primary teeth with no clinical symptoms or radiographic findings, which indicated total chronic pulpitis. These teeth were extracted and studied histologically by light microscopy. The pulp tissue in the roots of these teeth was healthy, based on the absence of any infiltration of mononuclear lymphocytes. The clinical and histological findings were in agreement in $81 \%$ of cases. However, in another study, the same author found a 59\% success rate among the histological and radiographic results in a 2-year follow-up of 33 primary molars pulpotomized with $\mathrm{Ca}(\mathrm{OH})_{2}$ paste. Internal dentin resorption was seen in almost half of the human teeth. ${ }^{84}$ Cvek $^{85}$ reported clinical and radiographic observations and a success rate of $96 \%$ when $\mathrm{Ca}(\mathrm{OH})_{2}$ (Calasept) was used as a wound dressing for direct pulp capping and partial pulpotomy in the traumatically exposed pulp of permanent teeth after a period of 14 to 60 months. Additionally, Holland et $\mathrm{al}^{86}$ reported complete hard tissue bridges on pulpotomies and pulp capping with $\mathrm{Ca}(\mathrm{OH})_{2}$ after 30 days in adult monkeys.

Calcium hydroxide has been used as a pulp capping agent to stimulate pulpal healing and dentin bridge formation in the permanent dentition, but it is not recommended as a pulp capping agent for pulpotomies in the primary dentition. Ozata et $\mathrm{al}^{87}$ compared a paste of $\mathrm{Ca}(\mathrm{OH})_{2}$ and formocresol in pulpotomies of 28 primary teeth in seven lambs. Their histological study examined the teeth under light microscopy at 1, 7, 14, 30, 60, 120 and 180-day intervals. They reported on the treatment of 14 teeth with $\mathrm{Ca}(\mathrm{OH})_{2}$, and 12 of 14 teeth treated with formocresol were histologically successful. They also reported on both $\mathrm{Ca}(\mathrm{OH})_{2}$ and formocresol pulpotomies causing the formation of reparative dentin in all of the teeth. In addition, they speculated that this result might be related to the healing potential of lamb pulp, which was considered to be greater than that of humans.

Cvek et $\mathrm{al}^{88}$ reported hard tissue barrier formation in pulpotomized monkey teeth capped with cyanoacrylate or $\mathrm{Ca}(\mathrm{OH})_{2}$ paste for 10 and 60 minutes. Their results suggested that the formation of a hard tissue barrier in exposed pulp was due to low-grade irritation. Additionally, Heide ${ }^{89}$ reported on a histological study using $\mathrm{Ca}(\mathrm{OH})_{2}$ (Dycal) as a pulpotomy capping material for 98 permanent incisors in 13 monkeys. After the teeth were exposed to the oral contamination for 4,48 or 168 hours, his results showed three categories of initial bridging, with the developments differing in the nature and rate of dentin bridge formation.

The main advantages of $\mathrm{Ca}(\mathrm{OH})_{2}$ are its antibacterial properties, its biocompatibility with the pulp tissue and its ability to stimulate hard-tissue formation. Heilig et $\mathrm{al}^{91}$ used $\mathrm{Ca}(\mathrm{OH})_{2}$ (Life) on pulpotomies of 17 carious primary mandibular molars. After 9 months, the treatment was a clinical success for all 17 teeth, and it was radiographically successful for 15 teeth, questionable for one tooth and unsuccessful for one tooth. Hard-tissue formation (dentin bridge) was reported in contact with some hard-setting hydroxide cements. ${ }^{92}$ The summary of the success rates of the studies ${ }^{17,24,29,39,40,55,59,76,77,84,91}$ using $\mathrm{Ca}(\mathrm{OH})_{2}$ as a pulpotomy medicament is provided in Table 2.

Table 2: The percentage of successes for the studies using calcium hydroxide as a pulpotomy medicament

\begin{tabular}{|c|c|c|c|c|c|}
\hline \multirow[b]{2}{*}{ Authors } & \multirow[b]{2}{*}{ Number of teeth } & \multirow[b]{2}{*}{ Time of observation (months) } & \multicolumn{3}{|c|}{ Percentage of success } \\
\hline & & & $C$ & $R$ & $H$ \\
\hline $\operatorname{Via}(1955)^{77}$ & 103 & 25 & - & 31 & - \\
\hline Law $(1956)^{24}$ & 227 & 60 & 46 & 46 & - \\
\hline \multirow[t]{3}{*}{ Doyl et al $(1962)^{17}$} & 18 & $0-12$ & 71 & - & - \\
\hline & 28 & $1-19$ & - & 64 & - \\
\hline & 17 & $0-12$ & - & - & 50 \\
\hline Magnusson $(1970)^{78}$ & 130 & 45 & - & 20 & 2.5 \\
\hline Schroder $(1978)^{85}$ & 33 & 24 & - & 59 & 59 \\
\hline Magnusson $(1980)^{29}$ & 119 & $3-45$ & - & - & 2 \\
\hline Heilig et al $(1984)^{91}$ & 17 & $3-9$ & 100 & 88 & - \\
\hline Huth et al $(2005)^{39}$ & 53 & 24 & 87 & - & - \\
\hline Markovic et al $(2005)^{40}$ & 33 & 18 & 82.3 & 76.5 & - \\
\hline Huth et al $(2012)^{55}$ & 46 & 36 & 75 & - & - \\
\hline Yildiz and Tosun $(2014)^{59}$ & 35 & 30 & 85 & 85 & - \\
\hline
\end{tabular}

C: Clinically; R: Radiographically; H: Histologically 
The main disadvantage of calcium hydroxide as a medicament in primary pulp therapy is the frequent finding of internal resorption. Investigations describing failures using $\mathrm{Ca}(\mathrm{OH})_{2}$ in primary teeth because of the frequent development of chronic pulpal inflammation and internal resorption include those by $\mathrm{Via}^{76}$ and Magnusson. ${ }^{77}$ In addition, Schroder ${ }^{91}$ reported that internal dentin resorption after pulpotomy for primary teeth occurred when using $\mathrm{Ca}(\mathrm{OH})_{2}$, in part because chronically inflamed pulp is present at the time of treatment or is induced by improper wound treatment, such as leaving a blood clot between the wound surface and the $\mathrm{Ca}(\mathrm{OH})_{2}$.

\section{GLUTARALDEHYDE}

Glutaraldehyde has been recommended as a substitute for formocresol in pulpotomy procedures in primary teeth. Gravenmade ${ }^{92}$ proposed that glutaraldehyde could be used as a new pulp fixative and that it offered the positive characteristics of formocresol without inducing the less desirable side effects because it is an active fixative agent that cross-links proteins by virtue of its two active sites. ${ }^{93}$ Glutaraldehyde has also demonstrated superior tissue fixation with relatively little immunogenicity, ${ }^{94,95}$ and it diffuses minimally through tissues. ${ }^{96}$ However, Rusmah and Rahim ${ }^{97}$ reported that $2 \%$ buffered glutaraldehyde did not diffuse out of the cementum and dentin of pulpotomized primary teeth in children. Additionally, there was no evidence of periapical inflammation.

Several studies have shown promising findings in clinical results. ${ }^{98,99}$ Compared with formocresol, less systemic distribution was also reported. ${ }^{100}$ GarciaGodoy ${ }^{101}$ used a $2 \%$ buffered glutaraldehyde solution on pulpotomies in children, followed them up for 19 to 42 months and reported the technique to be clinically and radiographically successful $98 \%$ of the time. Additionally, Fuks et $\mathrm{al}^{102}$ reported that the use of a $2 \%$ buffered glutaraldehyde solution on 53 pulpotomies in primary molars in children was clinically and radiographically successful $94 \%$ of the time after six months; then, the success rate decreased to $90 \%$ after 12 months. Following the same children, Fuks et al ${ }^{103}$ reported that the success rate decreased to $82 \%$ after 24 months, noting radiographically a high percentage of internal resorption. Parkash et $\mathrm{al}^{32}$ compared the use of formocresol or $2 \%$ glutaraldehyde on 60 carious pulpotomized primary molars in children. After 6 months, they found a clinical success rate of $100 \%$ in the glutaraldehyde group and $90 \%$ in the formocresol group. In 1990, Sun et a ${ }^{105}$ compared the cytotoxicity of glutaraldehyde and formaldehyde with regard to time exposure and concentration using cells from human fibroblast cell lines. These cells were exposed to a range of concentrations for periods of 4 to 24 hours. The authors found cytotoxic effects of formaldehyde over a narrow concentration range, which was not affected by the time of exposure. However, glutaraldehyde exerted its effects over a broader concentration range, and a longer exposure time was necessary for maximal toxicity. They suggested that a long contact time between glutaraldehyde and dental pulp was necessary for maximum fixation. Tsai et al ${ }^{106}$ reported on a clinical and radiographic study using four types of glutaraldehyde preparations, which included $2 \%$ buffered, $2 \%$ unbuffered, $5 \%$ buffered and $5 \%$ unbuffered, in 258 primary molar teeth of 201 children (108 boys and 93 girls, ages 4 to 7 years old). After 36 months, 150 children were available for evaluation. The success rate clinically was $98 \%$ but, radiographically, it was $79 \%$.

Davis et $\mathrm{a}^{107}$ reported a histological study that compared 5\% buffered glutaraldehyde to $2 \%$ diluted formocresol as medicaments on treated teeth. They reported that glutaraldehyde showed less penetration than formocresol; that only mild inflammation was seen in the glutaraldehyde group and was confined to the middle third of the radicular tissue, with only limited necrosis; and that the apical tissue was still vital in 78\% of the cases. They found no significant difference among the four groups. They also reported that glutaraldehyde might not be a better alternative to formocresol in primary teeth. Havale et $\mathrm{al}^{57}$ evaluated the clinical and radiographic success of 3 medicaments (formocresol, glutaraldehyde and ferric sulfate) following pulpotomies in primary molars at 3 monthly intervals over 1 year. The clinical success rates were $100 \%$ with glutaraldehyde, $96.7 \%$ with ferric sulfate, and $86.7 \%$ with formocresol after 1 year. The radiographic success rates in formocresol, glutaraldehyde, and ferric sulfate were 56.7, 83.3 and $63.3 \%$ respectively. A summary of the success rates of the studies ${ }^{32,57,98,101-103,105,107}$ using glutaraldehyde as a pulpotomy medicament is provided in Table 3 .

The literature lists several findings proposing that glutaraldehyde has advantages as a pulp medicament in primary teeth. Alacam ${ }^{108}$ reported that glutaraldehyde caused less apical damage and less necrosis in specimens than formocresol. Additionally, Rusmah ${ }^{109}$ reported on 42 pulpotomies performed on sound primary teeth in children using $2 \%$ buffered glutaraldehyde. After a 3 minutes application of glutaraldehyde, the histologic results showed a zone of surface fixation, which did not proceed apically. Glutaraldehyde was a better tissue fixative than formaldehyde, ${ }^{94}$ and its reaction products were less antigenic than those of formaldehyde and were not toxic when it was used as a pulpotomy agent. ${ }^{110}$ 
Pulpotomy Medicaments used in Deciduous Dentition: An Update

Table 3: The percentage of successes for the studies using glutaraldehyde as a pulpotomy medicament

\begin{tabular}{|c|c|c|c|c|c|}
\hline \multirow[b]{2}{*}{ Authors } & \multirow[b]{2}{*}{ Number of teeth } & \multirow[b]{2}{*}{ Time of observation (months) } & \multicolumn{3}{|c|}{ Percentage of success } \\
\hline & & & $C$ & $R$ & $H$ \\
\hline Kopel et al $(1980)^{107}$ & 30 & $0-12$ & 100 & - & 100 \\
\hline Garcia-Godoy (1983) & 55 & $6-18$ & 96 & 96 & - \\
\hline Garcia-Godoy $(1985)^{101}$ & 55 & 42 & 98 & - & - \\
\hline \multirow[t]{2}{*}{ Fuks et al $(1981)^{102}$} & 53 & 6 & 94 & 94 & - \\
\hline & 53 & 12 & 90 & 90 & - \\
\hline Prakash et al $(1988)^{32}$ & 20 & $1-6$ & 100 & 100 & - \\
\hline Fuks et al $(1989)^{103}$ & 53 & $6-25$ & 82 & 33 & - \\
\hline Tsai et al $(1993)^{105}$ & 150 & 36 & 98 & 79 & - \\
\hline Havale et al $(2013)^{57}$ & 30 & 12 & 100 & 83.3 & - \\
\hline
\end{tabular}

C: Clinically; R: Radiographically; H: Histologically

Nevertheless, one of the disadvantages of glutaraldehyde is that it is distributed systemically from pulpotomy sites at a higher rate than formocresol. ${ }^{111}$ Lloyd et $\mathrm{al}^{112}$ studied the histologic response of the dental pulp to $0.5,1.0$ or $2.0 \%$ glutaraldehyde applied to monkey teeth for 2,5 or 10 minutes. They found that, after 1 day of treatment, all of the samples had a zone of fixed pulp tissue. After one week and continuing through 8 weeks, they reported moderate chronic inflammation progressing to severe inflammation and internal resorption. The severity of the reaction was due to the lower concentration and shorter application of the medicament. For glutaraldehyde to be effective as an antimicrobial agent, there must be a high concentration, greater than $6.25 \%$, applied for more than 5 minutes. $^{72}$

\section{OTHER PROCEDURES AND MEDICAMENTS}

\section{Electrosurgery and Laser}

Electrosurgery has been used in dentistry to remove soft tissue and to control the hemorrhaging associated with periodontal and oral surgical procedures. In 1957, Laws ${ }^{113}$ reported the use of electro-coagulation pulpotomies on the pulp of permanent teeth in patients between the ages of 11 and 27 years old. After 4 months, the technique was found to produce inflammation in $37 \%$ of the treated cases. Yakuschji ${ }^{114}$ studied electrosurgical techniques for pulpotomies of six primary teeth. He found favorable pulpal responses when the teeth were examined at up to 13 days.

Ruemping et al ${ }^{115}$ studied the primary teeth of five Macaca nemestrina monkeys treated with either a conventional formocresol or an electrosurgical technique following pulpotomy. The post-treatment intervals were $2,3,4,5$, and 6 months. The results showed that the electrosurgical pulpotomy technique produced a tissue response comparable to that induced with formocresol pulpotomy techniques. Shulman et al ${ }^{116}$ compared electrosurgery and formocresol pulpotomy in four monkeys for periods of time of 3, 14, 41 and 65 days. The results showed that electrosurgical pulpotomy produced pathologic root resorption and periapical furcal pathology. In addition, when formocresol plus electrosurgery was used, better results were not produced compared to electrosurgery alone. Additionally, Sheller and Morton ${ }^{117}$ reported clinical and radiographic studies of 11 primary canines followed for up to 100 days after performing electrosurgical pulpotomies. Their results showed that 10 teeth were unremarkable clinically (radiographic results). Seven of the teeth demonstrated a variable histologic response but were still successful. All of the teeth showed some inflammation. Mack and Dean ${ }^{118}$ (1993) observed the clinical and radiographic results of an electrosurgical pulpotomy technique on 164 primary molars in children from 1 to 10 years old over a postoperative observation time ranging from 1 month to 5 years. Their results showed a $99.4 \%$ success rate on clinical and radiographic evaluation. In addition, compared to a formocresol pulpotomy study designed similarly, their success rate with the electrosurgical pulpotomy procedure was significantly higher than with formocresol. However, Oztas et $\mathrm{al}^{117}$ compared formocresol and an electrosurgical technique following pulpotomy of 16 primary molar teeth in four dogs for 1 month, and they found that formocresol pulpotomy was superior histopathologically to the electrosurgery technique. Dean et $\mathrm{al}^{118}$ compared electrosurgical pulpotomies with formocresol pulpotomies in children's primary molar teeth. After at least 5 months of postoperative observation time, the clinical and radiographic success rates of the electrosurgical groups were 96 and 84\% respectively, and for the formocresol groups, they were 100 and $92 \%$ respectively. Not only has formocresol medicament been compared with electrosurgery techniques, but calcium hydroxide has also been tested. Fishman et a $1^{119}$ observed electrofulguration pulpotomies on 47 primary molars in 38 patients using zinc oxide-eugenol and calcium hydroxide. The authors found that, after 6 months, the clinical success rates of zinc oxide egenol and calcium hydroxide were 77.4 and $81 \%$ 
respectively, while radiographically, the success rates were 54.6 and $57.3 \%$.

Shoji et $\mathrm{al}^{122}$ used a carbon dioxide laser on the uncovered pulp of 10 adult mongrel dogs. Histopathological examination of the pulp was performed immediately after irradiation. Their results showed that no detectable damage was observed in the radicular portion of the pulp that were irradiated. In contrast, Jukić et al ${ }^{123}$ studied the effects of pulpotomy using $\mathrm{CO}_{2}$ and Nd: YAG lasers on dental pulp tissue in the premolar and molar teeth of dogs for 30 and 45 days, and they found that laser irradiation initiated carbonization, necrosis, infiltration of inflammation cells, edema and hemorrhaging in the pulp tissue. There are a great number of variables making comparisons of electrosurgery and laser studies difficult, including sample sizes, techniques, amount of current used and the placement of different base materials over the treated pulp tissue. ${ }^{124}$ There seem to be some advantages of using electrosurgical and laser pulpotomy techniques. They can be performed rapidly, and there no pharmacotherapeutic agents that could produce undesirable local and systemic effects. There is also an absence of hemorrhaging and less mechanical damage to the underlying pulp. However, Shulman et $\mathrm{al}^{116}$ found that the electrosurgical technique produced pathologic root resorption and periapical/furcal morbidity.

\section{Ferric Sulfate}

Fei et $\mathrm{al}^{33}$ compared ferric sulfate with formocresol pulpotomies in 82 primary molars of 62 patients who were followed for 3-, 6- and 12-month periods. After 1 year, the follow-up results showed that $96 \%$ of teeth receiving ferric sulfate were considered successful, and $78 \%$ of teeth receiving formocresol were successful. Under the conditions of this experiment, better results were obtained using ferric sulfate than formocresol in the clinical and radiographic evaluations. Similarly, a study by Fuks et $\mathrm{al}^{34}$ compared ferric sulfate and diluted formocresol to treat 96 primary molars of 72 children followed for 6 to 34 months. The authors observed that the success rates clinically and radiographically were $94 \%$ for ferric sulfate and $84 \%$ for diluted formocresol. However, Cotes et al ${ }^{125}$ investigated, in a histological study, the pulp reaction to formocresol vs ferric sulfate and found that formocresol group showed less pulpal inflammation, and the use of ferric sulfate as alternative agent for pulpotomies did not improve pulpal response. Ibricevic and Al-Jame ${ }^{36}$ evaluated ferric sulfate with full-strength formocresol as pulpotomy medicaments in primary molars of children 42 to 48 months after treatment; their results showed a $96.4 \%$ success rate with ferric sulfate and a $97.5 \%$ success rate in the formocresol group clinically, while radiographically, the success rate with ferric sulfate pulpotomy was $92.0 \%$, compared to $94.6 \%$ with formocresol pulpotomy. Loh et a ${ }^{126}$ evaluated formocresol and ferric sulfate as pulpotomy medicaments using evidence-based dentistry principles. They reported that the clinical data indicated that ferric sulfate was highly statistically significantly more successful than formocresol, but the radiographic data showed no difference between the medicaments. Yadav et $\mathrm{al}^{125}$ evaluated and compared 45 primary molars treated with diode laser, electrosurgical and ferric sulfate pulpotomies. The clinical and radiographic success rates were evaluated after 9 months. They found an $86.6 \%$ success rate in the ferric sulfate group clinically, compared to a $100 \%$ clinical success rate in both the electrosurgical and diode laser groups. The radiographic success rate was $80 \%$ in all three of the groups at the end of 9 months. They also reported that internal resorption appeared to be the most common cause of failure after pulpotomy. A summary of the success rates of the studies $^{33-36,39,40,49,55,57,59,60,127}$ using ferric sulfate as a pulpotomy medicament is provided in Table 4.

Table 4: The percentage of successes for the studies using ferric sulfate as a pulpotomy medicament

\begin{tabular}{|c|c|c|c|c|c|}
\hline \multirow[b]{2}{*}{ Authors } & \multirow[b]{2}{*}{ Number of teeth } & \multirow[b]{2}{*}{ Time of observation (months) } & \multicolumn{3}{|c|}{ Percentage of success } \\
\hline & & & $C$ & $R$ & $H$ \\
\hline Fei et al $(1990)^{33}$ & 29 & 12 & 100 & 97 & - \\
\hline Fuks et al $(1996)^{34}$ & 51 & 35 & 92.7 & 74.5 & - \\
\hline Papagiannoulis et al (2002) ${ }^{35}$ & 66 & 36 & 90.3 & 74 & - \\
\hline Ibricevic and Al-Jame $(2003)^{36}$ & 81 & $42-48$ & 96.4 & 93.7 & - \\
\hline Huth et al $(2005)^{39}$ & 86 & 24 & 100 & 100 & - \\
\hline Markovic et al $(2005)^{40}$ & 33 & 18 & 89.2 & 81.1 & - \\
\hline Gisoure $(2011)^{49}$ & 27 & 9 & 96.4 & 85.7 & - \\
\hline Huth et al $(2012)^{55}$ & 76 & 36 & 97 & - & - \\
\hline Havale et al $(2013)^{57}$ & 29 & 12 & 96.7 & 63.3 & - \\
\hline Yadav et al $(2014)^{127}$ & 45 & 9 & 86.6 & 80 & - \\
\hline Durmus and Tanboga $(2014)^{60}$ & 40 & 12 & 95 & 79 & - \\
\hline Yildiz and Tosun $(2014)^{59}$ & 35 & 30 & 95.2 & 85.7 & - \\
\hline
\end{tabular}

C: Clinically; R: Radiographically; H: Histologically 


\section{Freeze-dried Bone}

Fadavi et al ${ }^{128}$ evaluated the effects of freeze-dried bone on amputated pulp in 15 primary and one permanent monkey teeth. They compared these teeth with teeth treated with $\mathrm{Ca}(\mathrm{OH})_{2}$ and formocresol. Freeze-dried bone showed a complete or partial calcific barrier directly below the amputation site, and similar results were shown in the $\mathrm{Ca}(\mathrm{OH})_{2}$ group after 3 months; however, the results in the formocresol group were comparable to those of previously published studies.

\section{Bone Morphogenetic Protein}

In 1990, Nakashima ${ }^{129}$ reported a histological study using bone morphogenetic protein in 50 teeth of five young adult dogs. The study was undertaken at time periods of 1,4 and 8 weeks. The results showed that reparative dentin formed in the cavity of the amputated pulp when capped with crude allogenic bone morphogenetic protein. In addition, 8 weeks postoperatively, odontoblasts were forming tubular dentin next to the osteodentin.

\section{Osteogenic Protein-1}

In 1993, Rutherford et $\mathrm{al}^{130}$ undertook a histological study using human osteogenic protein-1 combined with collagen matrix. Their results showed that reparative dentin was present in all teeth that remained sealed for the 6 weeks. However, more new dentin was present in teeth treated with human osteogenic protein-1/collagen matrix than in those treated with calcium hydroxide paste.

\section{The Novel Anti-inflammatory Agent Tetrandrine}

In 1993, Seow and Thong ${ }^{131}$ evaluated tetrandrine, a bisbenzyl-isoquinoline alkaloid with unique broadspectrum anti-inflammatory properties, as a pulpotomy medicament in a mongrel dog with permanent teeth. The histological results showed acute inflammation after 3 days and chronic inflammation after 6 weeks. They also reported that tetrandrine resulted in significantly less inflammation than in teeth treated using formocresol and lead mix cement.

\section{Collagen}

Nevins et $\mathrm{al}^{132}$ reported a histological study using collagen-calcium phosphate gel on pulpotomies of the teeth of nine rhesus monkeys that were followed for 4 to 8 months. The results showed gel resorption and hardtissue replacement in 14 of 16 teeth, with no inflammation observed in long-term samples. Bimstein and Shoshan ${ }^{133}$ reported a histological study using collagen solutionenriched cell nutrients for pulpotomies of the anterior permanent incisors of young dogs. After 30 days, they noted complete regeneration of pulpal tissue. Fuks et $\mathrm{al}^{134}$ used enriched collagen solution for pulpotomies of primary teeth in monkeys. After 60 days, all of the collagen-treated teeth showed a normal radiographic appearance of dentin with bridge formation. After 60 days, $80 \%$ of the teeth had vital pulp, and the other $20 \%$ showed severe inflammation.

\section{Feracrylum}

Prabhu and Munshi ${ }^{135}$ attempted to use 1\% feracylum (Hemolok, pH 3.4), which is an incomplete iron salt of polyacrylic acid containing 0.05 to $0.5 \%$ iron, for pulpotomies of 26 primary molars of dogs. They found that the teeth were clinically and radiographically asymptomatic, and histological evaluation showed evidence of healing in the form of reparative dentin and fibrous tissue formation the deeper zone of the radicular pulp.

\section{Glass lonomer}

Glass ionomer was developed as dental cement. Wilson and Kent $^{136}$ introduced this cement to the dental profession in 1972. Glass ionomer cement is the product of the silicate glass of alkaline earth metals reacting with an aqueous solution of acrylic acid. The cement was formerly called alumino-silicate-polyacrylate cement, abbreviated ASPA. Glass ionomer cements were used as restorative materials in a clinical effort in Europe in 1975 and in North America in 1977. Fuji Ionomer Type I was produced in Japan as a luting cement in 1977. Since then, manufacturers have continued to develop the product, and many products are available today for multiple uses, such as for crown cementation, for the restoration of class III and V caries lesions in permanent, primary teeth and for emergency repair of fractured teeth and fissure sealants. Wilson and McLean ${ }^{137}$ classified the glass ionomer cements into three categories based on clinical use: type I luting cement; type II restorative material: (a) esthetic and (b) reinforced; and type III fast-setting lining material and fissure sealant. In the late 1980s, Mitia developed Vitrebond (light-cured glass ionomer liner base). Manufacturers have concentrated on developing a similar restorative material with improved strength. ${ }^{138}$ In early 1992, a light-hardened glass ionomer resin dental restorative cement (Fuji II LC) was introduced. ${ }^{139}$ Among the various products, the formulation generally consists of $80 \%$ glass ionomer combined with $20 \%$ light-hardened resin. The exact components differ from type to type. The addition of resin to a glass ionomer improves the physical properties, compared to self-hardening glass ionomer cement. 
Several studies have been performed using glass ionomer cement as an indirect pulp capping material. However, very few studies have been undertaken using glass ionomer as a direct pulp capping agent. Hume and Mount ${ }^{140}$ reported in vitro studies of the potential for pulpal cytotoxicity of glass ionomer cement. Glass ionomer cement was placed in sterile tissue culture medium, either by direct contact or through a disk of human dentin, and then was tested for toxicity using cultured mouse fibroblasts. The results showed that the direct culturing tests were highly sensitive; however, tests using a disk of dentin were of limited value because, apparently, the dentin reduced the potential for the cytotoxicity of glass ionomer. Additionally, the $\mathrm{pH}$ was reduced to neutrality because no cytotoxicity occurred. Felton et $\mathrm{al}^{141}$ evaluated, in a histological study, the influence of light-cured glass ionomer cavity liner, chemically cured Ketac and bond glass ionomer restorative material on the pulpal tissue of monkeys. Class $\mathrm{V}$ cavities were prepared in 71 teeth of monkeys, which were sampled at 7 to 35 days. Glass ionomer of both types was placed in the cavities, which were then restored with composite resin. The histological results showed minimal pulp reactions in both groups, indicating excellent pulpal responses to both materials.

\section{Mineral Trioxide Aggregate}

In 1995, mineral trioxide aggregate (MTA) was introduced by Torabinejad et $\mathrm{al}^{142}$ and it is comprised of tricalcium silicate, tricalcium calcium aluminate, tricalcium oxide and silicate oxide; hydration of MTA produces a colloidal gel when MTA is mixed with water, and it has a $\mathrm{pH}$ of 12. A gray-colored MTA was first used, and later a white-colored MTA was introduced to improve the tooth coloration. Mineral trioxide aggregate has many advantages, such as good biocompatibility, bactericidal potential, induction of cementogenesis, sealing ability, and the ability to induce hard tissue formation, and it has been used for apexogenesis and the apexification of immature teeth. ${ }^{143-145}$

Eidelman et al ${ }^{146}$ compared the effects of MTA to those of formocresol as a pulp-dressing agents in pulpotomized primary molars with carious pulp exposure. Forty-five primary molars of 26 children were treated with both agents; the follow-up evaluations revealed only one failure (internal resorption detected at a 17 months postoperative evaluation) in a molar treated with formocresol. None of the MTA-treated teeth showed any clinical or radiographic pathology. Obliteration of the pulp canal was noticed in nine of the $32(28 \%)$ evaluated molars. These results were detected in two of the 15 teeth treated with formocresol $(13 \%)$ and in seven of the 17 teeth treated with MTA (41\%).

Agamy et $\mathrm{al}^{37}$ performed clinical, radiographic, and histologic examinations to compare the relative success of gray MTA, white MTA, and formocresol as pulp dressings in pulpotomized primary teeth. They concluded that gray MTA appeared to be superior to white MTA and formocresol as a pulp dressing for pulpotomized primary teeth. In the histologic study, both types of MTA successfully induced thick dentin bridge formation at the amputation spot, whereas formocresol induced thin, poorly calcified dentin. Holan et $\mathrm{al}^{42}$ reported the effects of MTA as a pulp dressing material following pulpotomy of primary molars with carious pulp exposure, and they compared these effects to those of formocresol. The success rate of pulpotomy was $97 \%$ for the MTA group (33 teeth, one failure) and $83 \%$ for the formocresol group (29 teeth, five failures). Eight teeth presented internal resorption. In four of them (two in each group), the resorption process stopped, and the pulp tissue was replaced by radiopaque, calcified tissue. Pulp canal obliteration was noted in $58 \%$ of the MTA group and $52 \%$ of the formocresol group (total $=55 \%$ ). Farsi et al ${ }^{41}$ compared, clinically and radiographically, MTA with formocresol when used as medicaments in pulpotomized vital human primary molars. The sample consisted of 120 primary molars. At the end of the 24 months evaluation period, 74 molars (36 formocresol, 38 MTA) were available for clinical and radiographic evaluation. None of the MTA-treated teeth showed any clinical or radiographic pathology, while the formocresol group showed success rates of $86.8 \%$ radiographically and $98.6 \%$ clinically. The difference between the two groups in radiographic outcomes was statistically significant. It was concluded that the MTA-treated molars demonstrated significantly superior success. Mineral trioxide aggregate appears to be a suitable replacement for formocresol in pulpotomized primary teeth.

A comparison of four pulpotomy techniques (formocresol, ferric sulfate, calcium hydroxide $\left(\mathrm{Ca}(\mathrm{OH})_{2}\right)$, and MTA) as pulp dressing agents in pulpotomized primary molars was performed by Sonmez et al. ${ }^{147}$ Eighty selected teeth were divided into four groups and were treated with one of the pulpotomy medicaments. The children were followed up for clinical and radiographic examinations every 6 months over 2 years. Eleven of 16 children with 56 teeth arrived for clinical and radiographic follow-up evaluations at 24 months. The success rates were $76.9 \%$ for formocresol, $73.3 \%$ for 
ferric sulfate, $46.1 \%$ for $\mathrm{Ca}(\mathrm{OH})_{2}$, and $66.6 \%$ for MTA. In conclusion, $\mathrm{Ca}(\mathrm{OH})_{2}$ is less appropriate for primary teeth pulpotomies than the other pulpotomy agents, and formocresol and ferric sulfate appeared to be superior to the other medicaments. Nevertheless, there were no statistically significant differences among the groups. The clinical and the radiographic success rates for MTA as a pulpotomy medicament in primary teeth have ranged from 88 to $100 \%$, as published in several studies, $37,38,41-48,50-54,56,58,59,61,148$ which are shown in Table 5. These studies revealed that, for pulpotomy of vital primary teeth, MTA had better treatment outcomes than formocresol, ferric sulfate, calcium and hydroxide.

\section{Lyophilized Freeze-dried Platelet-derived Preparation}

Kalaskar and Damle ${ }^{149}$ compared the efficacy of a lyophilized freeze-dried platelet-derived preparation to that of calcium hydroxide as pulpotomy agents in primary molars. Fifty-six primary molars in 28 children were treated by a conventional pulpotomy technique. Twenty-eight teeth were treated with the lyophilized freeze-dried platelet-derived preparation and another 28 with calcium hydroxide. Clinical evaluations were performed at 1, 3 and 6 months, and radiographic evaluations were performed at 1 and 6 months. The authors reported that the success rate with the lyophilized freeze-dried platelet-derived preparation was better than that with calcium hydroxide.

\section{Enamel Matrix Derivative}

Sabbarini et $\mathrm{al}^{150}$ evaluated histologically the effects of an enamel matrix derivative as a pulpotomy agent in primary canines. Emdogain gel was used as the pulp dressing material on the removed pulp stumps; then, the teeth were extracted postoperatively after 1 week, 2 weeks and 6 months. The teeth were examined histologically to assess the response of the pulp to Emdogain gel after the pulpotomy procedure. After 1 week, in the extracted teeth, the amputated pulpal surface was lined by a thin, virtually continuous cellular layer. Wideranging congestion was accompanied by an increase in angiogenesis. After 2 weeks, most of the teeth showed little islands of dentin-like tissue at different stages of mineralization. After 6 months, a number of different histological appearances were observed. The majority of the teeth showed coalescing islands of dentin-like tissue attempting to bridge the full width of the coronal pulp at the interface between the wounded and unharmed pulp tissue below the amputation site. The authors concluded that Emdogain gel showed promising results as a valuable material for use in pulpotomy procedures. In another study by Sabbarini et al, $^{151}$ the authors compared the clinical and radiographic success rates of enamel matrix derivative to those with formocresol. A randomized, single-blind, split-mouth study was used with a sample of 15 pairs of children. All of the teeth were followed up clinically and radiographically at 2, 4, and 6 months. After 6 months, the clinical success rates for the formocresol

Table 5: The percentage of successes for the studies using MTA as a pulpotomy medicament

\begin{tabular}{|c|c|c|c|c|c|}
\hline \multirow[b]{2}{*}{ Authors } & \multirow[b]{2}{*}{ Number of teeth } & \multirow{2}{*}{$\begin{array}{l}\text { Time of observation } \\
\text { (months) }\end{array}$} & \multicolumn{3}{|c|}{ Percentage of success } \\
\hline & & & $C$ & $R$ & $H$ \\
\hline Agamy et al $(2004)^{37}$ & 19 & 12 & 100 & 100 & - \\
\hline Jabbarifar et al $(2004)^{38}$ & 30 & 12 & 94 & 94 & 一 \\
\hline Farsi et al $(2005)^{41}$ & 38 & 24 & 100 & 100 & - \\
\hline Holan et al $(2005)^{42}$ & 32 & 74 & 97 & 97 & - \\
\hline Naik and Hedge $(2005)^{43}$ & 24 & 6 & 100 & 100 & 一 \\
\hline Aeinehchi et al $(2007)^{44}$ & 43 & 6 & 100 & 100 & - \\
\hline Maroto et al $(2007)^{148}$ & 69 & 42 & 100 & 98.5 & - \\
\hline Subramaniam et al $(2009)^{45}$ & 20 & 24 & 100 & 95 & - \\
\hline Zealand et al $(2010)^{46}$ & 100 & 6 & 100 & 95 & - \\
\hline Ansari and Ranjpour (2010) ${ }^{47}$ & 15 & 24 & 100 & 100 & - \\
\hline Hugar and Deshpande $(2010)^{48}$ & 30 & 36 & 100 & 100 & - \\
\hline Erdem et al $(2011)^{50}$ & 24 & 24 & 96 & 96 & - \\
\hline Godhi et al $(2011)^{51}$ & 25 & 12 & 100 & 96 & - \\
\hline Srinivasan and Jayanthi $(2011)^{52}$ & 47 & 12 & 100 & 95.7 & - \\
\hline Sushynski et al $(2012)^{53}$ & 65 & 24 & 100 & 95 & - \\
\hline Airen et al $(2012)^{54}$ & 34 & 24 & 97 & 88.6 & - \\
\hline Mettlach et al $(2013)^{56}$ & 119 & 42 & 100 & 95 & 一 \\
\hline Jayam et al $(2014)^{58}$ & 40 & 24 & 100 & 100 & - \\
\hline Yildiz and Tosun $(2014)^{59}$ & 35 & 30 & 96.4 & 96.4 & - \\
\hline Olatosi et al $(2015)^{61}$ & 25 & 12 & 100 & 96 & - \\
\hline
\end{tabular}

C: Clinically; R: Radiographically; H: Histologically 
and enamel matrix derivative groups were 67 and 93\% respectively, and the radiographic success rates were 13\% for formocresol and $60 \%$ for enamel matrix derivative. The authors reported that the clinical and radiographic assessment of enamel matrix derivative-pulpotomized teeth showed that enamel matrix derivative is a promising material that could be as successful as other pulpotomy agents.

\section{Sodium Hypochlorite}

It is well known that sodium hypochlorite irrigation solution has been very common used solution in endodontic treatment. The advantages of sodium hypochlorite include its antimicrobial and detergent action, tissue dissolving ability, and homeostatic action. Vargas et a ${ }^{152}$ compared the effectiveness of $5 \%$ sodium hypochlorite to that of ferric sulfate as a pulpotomy medicament in decayed primary molars. The clinical and radiographic signs/symptoms were recorded at 0, 6 and 12 months. Their results showed that, at 12 months, ferric sulfate resulted in $85 \%$ clinical success and $62 \%$ radiographic success. Sodium hypochlorite resulted in $100 \%$ clinical success and $79 \%$ radiographic success. Vostatek et $\mathrm{al}^{153}$ reported on a retrospective study of sodium hypochlorite pulpotomies with a $95 \%$ clinical success rate and an $82 \%$ overall radiographic success rate. Al-Mutairi and Bawazir ${ }^{154}$ compared the clinical and radiographic success rates of $5 \%$ sodium hypochlorite and $20 \%$ formocresol as pulpotomy medicaments in carious primary molars. The authors found that the clinical and radiographic success rates were 94.6 and $86.5 \%$ respectively, for sodium hypochlorite and $92.1 \%$ and $86.8 \%$ for formocresol after 12 months. Another study by Shabzendedar et $\mathrm{al}^{155}$ evaluated the effects of $3 \%$ sodium hypochlorite and formocresol as pulp dressing agents in pulpotomized primary molars. The results of their study showed that, at 6 months, 100\% clinical success was found with both sodium hypochlorite and formocresol. The radiographic success rates for sodium hypochlorite were 98 and $92 \%$ at the 6- and 12-month follow-ups respectively. The formocresol group showed 94 and $93 \%$ radiographic success rates at the same time points. Ruby et al ${ }^{156}$ compared the clinical and radiographic success rates of vital pulpotomy treatment in primary molars using 3\% sodium hypochlorite with a 1:5 dilution of Buckley's formocresol. The authors reported that $100 \%$ clinical success and $80 \%$ radiographic success for sodium hypochlorite at 12 months. The effects of sodium hypochlorite application on the success of calcium hydroxide and mineral trioxide aggregate pulpotomies in primary teeth were evaluated recently by Akcay and Sari ${ }^{157}$ They concluded that the use of sodium hypochlorite as an antibacterial agent prior to application of the pulpotomy agent improved the success of calcium hydroxide pulpotomies to equal that of mineral trioxide aggregate pulpotomies over observation of up to 12 months.

\section{Portland Cement}

Pulpotomies with Portland cement as a medicament in human primary molars were performed by Conti et al. ${ }^{158}$ Pulpotomy using Portland cement was performed in 3 molars, and at 12 months, clinical and radiographic examinations revealed that the treatments were successful in keeping the teeth asymptomatic and in preserving pulpal vitality. Furthermore, the formation of a dentin bridge immediately below the Portland cement could be observed in the three molars treated. The authors reported that Portland cement could be considered an effective alternative for primary molar pulpotomies. Sakai et al ${ }^{159}$ compared the clinical and radiographic effectiveness of MTA and Portland cement as pulp dressing agents in carious primary teeth. They reported that all of the pulpotomized teeth were clinically and radiographically successful at 2 years. The authors reported that no statistically significant difference regarding dentin bridge formation was found between the groups throughout the follow-up period. Steffen and van Waes ${ }^{160}$ reviewed 50 papers concerning MTA and Portland cement with consideration of the clinical, biological and mechanical findings and the possible substitution of MTA with Portland cement for endodontic use. Their results showed that MTA and Portland cement had the same clinical, biological and mechanical characteristics. In animal experiments and practical characterizations, both materials seemed to have very equivalent properties. The only difference was bismuth oxide was added to MTA for improved radiopacity.

\section{Nanohydroxyapatite}

Nanohydroxyapatite was used as a pulpotomy and direct pulp capping agent in primary pig teeth by Shayegan et al. ${ }^{161}$ The results of the their histological study revealed that, in the short-term and in caries-free pig teeth, nanohydroxyapatite appeared to be biocompatible and provoked no moderate or severe inflammatory reaction in pulp tissues with either pulpotomy or direct pulp capping treatments.

\section{Calcium-enriched Mixture}

Malekafzali et al ${ }^{162}$ compared calcium-enriched mixture cement and MTA as pulp dressing biomaterials in vital pulpotomies of carious primary molars. The authors 
reported that, at the 12-month follow-up, only one and three teeth in the two groups had pathologic root resorption. The resorbed teeth were then lost due to extraction/exfoliation at the 24-month follow-up; all of the other treated teeth were free of signs and symptoms. In general, the clinical and radiographic outcomes with both the calcium-enriched mixture cement and MTA groups were comparable at the three follow-ups, without significant differences.

\section{Calcium Phosphate Cement}

Jose et al $^{163}$ compared calcium phosphate cement with formocresol. Histological assessment for non-carious primary canines after 70 days showed no statistically significant differences between the two groups in any of the parameters. However, calcium phosphate cement provided more favorable results of less pulpal inflammation and better formation of dentin bridges in quantity and quality; it was also capable of inducing dentin formation without an area of necrosis.

\section{Allium Sativum Oil}

Recently, Mohammad et $\mathrm{l}^{164}$ compared the clinical and radiographic effects of $A$. sativum oil and those of formocresol in vital pulpotomies of primary teeth. Their results showed that $\mathrm{A}$. sativum oil had good healing potential, leaving the remaining pulp tissue functioning and healthy. Vital pulpotomy with A. sativum oil had a $90 \%$ success rate, while that with formocresol was $85 \%$. The authors concluded that A. sativum oil is a biocompatible material that is compatible with vital human pulp tissue. It has good healing potential and leaves the remaining pulp tissue healthy and functioning.

\section{SUMMARY}

Based on a review of the literature, it has been shown that pulpotomy of primary teeth can be treated using many different techniques and medicaments, that some of these treatments are debatable and that their results have presented variables success rates clinically, radiographically and histologically. This review paper has presented the available literature, which has reported on more than twenty medicaments for pulpotomy of primary teeth, many of which have been tried as alternatives to formocresol. In addition, we could conclude the following from this literature review on pulpotomy of primary teeth.

- Formocresol has been and remains the most popular pulpotomy medicament, and it is still the gold standard for comparisons with new medicaments, although its clinical toxicity has been reported in some literature.
- Ferric sulfate has obtained considerable favor as a result of formocresol's disadvantages for pulpotomy of primary teeth.

- Mineral trioxide aggregate has shown high success rates clinically and radiographically, and it might offer the best immediate alternative to the other medicaments reviewed in this paper.

- Sodium hypochlorite has been suggested as a pulpotomy agent for primary tooth pulpotomies, and several recent studies have shown the success rate for sodium hypochlorite pulpotomy to be comparable to that for formocresol pulpotomy.

\section{REFERENCES}

1. Sonarkar S, Purba R. Bioactive materials in conservative dentistry. International Journal of Contemporary Dental and Medical Reviews 2015, Article ID: 340115, 2015. doi: 10.15713/ ins.ijcdmr.47.

2. Koecker L. Principles of dental surgery; 1826.

3. Beaver HA, Kopel HM, Sabes WR. The effect of zinc oxideeugenol cement on a formocresolized pulp. ASDC J Dentistry for Children 1966;33(6):381-396.

4. Glass RL, Zander HA. Pulp healing. J Dent Res 1949;28(2): 97-107.

5. Buckley JP. The chemistry of pulp decomposition, with a rational treatment for this condition and its sequelae. Amer Dent J 1904;3:764-771.

6. Sweet C. Root-canal treatment in deciduous teeth, including pulp exposure. Pacific Dent Gaz 1923;31:718-721.

7. Sweet CA. Procedure for treatment of exposed and pulpless deciduous teeth* Journal of the American Dental Association 1930;17(6):1150-1153.

8. Hess W. Pulp amputation as a method of treating root canals. D Items Int 1929;51:596.

9. Foster HR. The Pulpless Deciduous Teeth* Journal of the American Dental Association 1936;23(11):2057-2065.

10. Strange EM. Is Vital Pulpotomy Worthwhile? ASDC J Dent Child 1953;20:38-40.

11. Nacht MA. Devitalizing technic for pulpotomy in primary molars. ASDC J Dent Child 1956;23(1st quart):45.

12. Wong K-C. Effects of paraformaldehyde preparations on the periapical tissues in non-vital pulpotomy procedures. Chicago: Northwestern University; 1958.

13. Massler M, Mansukhani N. Effects of formocresol on the dental pulp. ASDC J Dent Child 1959;26(1):277-297.

14. Emmerson C, Miyamoto O, Sweet C, Bhatia H. Pulpal changes following formocresol applications on rat molars and human primary teeth. JS Calif Dent Assoc 1959;27:309-323.

15. Dietz DR. A histologic study of the effects of formocresol on normal primary pulpal tissue: MS thesis. University of Washington, Seattle; 1961.

16. Doyle WA. A comparison of the formocresol pulpotomy technique with the calcium hydroxide pulpotomy technique. 1961.

17. DoyleWA,McDonaldR,MitchellD.Formocresolversuscalcium hydroxide in pulpotomy. ASDC J Dent Child 1962;29(2):86-97.

18. Spedding RH. The effect of formocresol and calcium hydroxide on the dental pulps of Rhesus monkeys. 1963. 
19. Redig DF. A comparison and evaluation of two formocresol pulpotomy technics utilizing 'Buckley's' formocresol. ASDC J Dent Child 1968;35(1):22-30.

20. Straffon L, Han S. The effect of formocresol on hamster connective tissue cells, a histologic and quantitative radioautographic study with proline-H 3. Archives of Oral Biology 1968;13(3):271-IN215.

21. Morawa A, Straffon L, Han S, Corpron R. Clinical evaluation of pulpotomies using dilute formocresol. ASDC J of Dent Child 1974;42(5):360-363.

22. Fuks AB, Bimstein E. Clinical evaluation of diluted formocresol pulpotomies in primary teeth of school children. Pediatr Dent 1981;3(4):321-324.

23. Sweet C. Formocresol technique. Paper presented at: Transactions of the Third International Conference on Endodontics, University of Pennsylvania, Philadelphia, 1963.

24. Law DB, Lewis TM. Formocresol pulpotomy in deciduous teeth. J Am Dent Assoc 1964;69:601-607.

25. Berger JE. Pulp tissue reaction to formocresol and zinc oxideeugenol. ASDC J Dent Child 1965;32:13-28.

26. Rolling I, Thylstrup A. A 3-year clinical follow-up study of pulpotomized primary molars treated with the formocresol technique. Scand J Dent Res 1975;83(2):47-53.

27. Magnusson BO. Therapeutic pulpotomies in primary molars with the formocresol technique. A clinical and histological follow-up. Acta Odontol Scand 1978;36(3):157-165.

28. Mejàre I. Pulpotomy of primary molars with coronal or total pulpitis using formocresol technique. European Journal of Oral Sciences 1979;87(3):208-216.

29. Magnusson B. Pulpotomy in primary molars: long-term clinical and histological evaluation. Int Endodon J 1980;13(3): 143-155.

30. Garcia-Godoy F. Direct pulp capping and partial pulpotomy with diluted formocresol in primary molars. Acta Odontol Pediatr 1984;5(2):57-61.

31. Hicks M, Barr E, Flaitz C. Formocresol pulpotomies in primary molars: a radiographic study in a pediatric dentistry practice. The Journal of pedodontics 1985;10(4):331-339.

32. Prakash C, Chandra S, Jaiswal J. Formocresol and glutaraldehyde pulpotomies in primary teeth. The Journal of pedodontics 1988;13(4):314-322.

33. Fei A-L, Udin RD, Johnson R. A clinical study of ferric sulfate as a pulpotomy agent in primary teeth. Pediatric dentistry 1990;13(6):327-332.

34. Fuks A, Holan G, Davis J, Eidelman E. Ferric sulfate versus dilute formocresol in pulpotomized primary molars: longterm follow up. Pediatric Dentistry 1996;19(5):327-330.

35. Papagiannoulis L. Clinical studies on ferric sulphate as a pulpotomy medicament in primary teeth. Eur J Paediatr Dent 2002;3(3):126-132.

36. Ibricevic $\mathrm{H}, \mathrm{Al}-\mathrm{Jame} \mathrm{Q}$. Ferric sulphate and formocresol in pulpotomy of primary molars: long term follow-up study. Eur J Paediatr Dent 2003;4(1):28-32.

37. Agamy HA, Bakry NS, Mounir MMF, Avery DR. Comparison of mineral trioxide aggregate and formocresol as pulpcapping agents in pulpotomized primary teeth. Pediatric Dentistry 2004;26(4):302-309.

38. Jabbarifar S, Khademi A, Ghasemi D. Success rate of formocresol pulpotomy versus mineral trioxide aggregate in human primary molar tooth. J Research in Medical Sciences 2004;9(6):304-307.
39. Huth K, Paschos E, Hajek-Al-Khatar N, Hollweck R, Crispin A, Hickel R, et al. Effectiveness of 4 pulpotomy techniques-randomized controlled trial. Journal of dental research 2005;84 (12):1144-1148.

40. Markovic D, Zivojinovic V, Vucetic M. Evaluation of three pulpotomy medicaments in primary teeth. Eur J Paediatr Dent 2005;6(3):133-138.

41. Farsi N, Alamoudi N, Balto K, Mushayt A. Success of mineral trioxide aggregate in pulpotomized primary molars. J Clin Pediatr Dent 2005;29(4):307-311.

42. Holan G, Eidelman E, Fuks AB. Long-term evaluation of pulpotomy in primary molars using mineral trioxide aggregate or formocresol. Pediatr Dent 2005;27(2):129-136.

43. Naik S, Hegde AM. Mineral trioxide aggregate as a pulpotomy agent in primary molars: an in vivo study. Journal of Indian Society of Pedodontics and Preventive Dentistry 2005;23(1):13.

44. Aeinehchi M, Dadvand S, Fayazi S, Bayat-Movahed S. Randomized controlled trial of mineral trioxide aggregate and formocresol for pulpotomy in primary molar teeth. Int Endod J 2007;40(4):261-267.

45. Subramaniam P, Konde S, Mathew S, Sugnani S. Mineral trioxide aggregate as pulp capping agent for primary teeth pulpotomy: 2 year follow up study. J Clin Pediatr Dent 2009; 33(4):311-314.

46. Zealand CM, Briskie DM, Botero TM, Boynton JR, Hu JC. Comparing gray mineral trioxide aggregate and diluted formocresol in pulpotomized human primary molars. Pediatr Dent 2010;32(5):393-399.

47. Ansari G, Ranjpour M. Mineral trioxide aggregate and formocresol pulpotomy of primary teeth: a 2-year follow-up. Int Endod J 2010;43(5):413-418.

48. Hugar SM, Deshpande SD. Comparative investigation of clinical/radiographical signs of mineral trioxide aggregate and formocresol on pulpotomized primary molars. Contemp Clin Dent 2010;1(3):146-151.

49. Gisoure EF. Comparison of three pulpotomy agents in primary molars: a randomised clinical trial. Iranian endodontic journal 2011;6(1):11.

50. Erdem AP, Guven Y, Balli B, Ilhan B, Sepet E, Ulukapi I, et al. Success rates of mineral trioxide aggregate, ferric sulfate, and formocresol pulpotomies: a 24 month study. Pediatr Dent 2011;33(2):165-170.

51. Godhi B, Sood PB, Sharma A. Effects of mineral trioxide aggregate and formocresol on vital pulp after pulpotomy of primary molars: An in vivo study. Contemp Clin Dent 2011;2(4):296-301.

52. Srinivasan D, Jayanthi M. Comparative evaluation of formocresol and mineral trioxide aggregate as pulpotomy agents in deciduous teeth. Indian J Dent Res 2011;22(3): 385-390.

53. Sushynski JM, Zealand CM, Botero TM, Boynton JR, Majewski RF, Shelburne CE, et al. Comparison of gray mineral trioxide aggregate and diluted formocresol in pulpotomized primary molars: a 6- to 24-month observation. Pediatr Dent 2012;34(5):120-128.

54. Airen P, Shigli A, Airen B. Comparative evaluation of formocresol and mineral trioxide aggregate in pulpotomized primary molars-2-year follow-up. J Clin Pediatr Dent 2012;37(2):143-147. 
55. Huth KC, Hajek-Al-Khatar N, Wolf P, Ilie N, Hickel R, Paschos E. Long-term effectiveness of four pulpotomy techniques: 3 year randomised controlled trial. Clin Oral Investig 2012;16(4):1243-1250.

56. Mettlach SE, Zealand CM, Botero TM, Boynton JR, Majewski RF, Hu JC. Comparison of mineral trioxide aggregate and diluted formocresol in pulpotomized human primary molars: 42-month follow-up and survival analysis. Pediatr Dent 2013;35(3):E87-94.

57. Havale R, Anegundi RT, Indushekar K, Sudha P. Clinical and radiographic evaluation of pulpotomies in primary molars with formocresol, glutaraldehyde and ferric sulphate. Oral Health Dent Manag 2013;12(1):24-31.

58. Jayam C, Mitra M, Mishra J, Bhattacharya B, Jana B. Evaluation and comparison of white mineral trioxide aggregate and formocresol medicaments in primary tooth pulpotomy: clinical and radiographic study. J Indian Soc Pedod Prev Dent 2014;32(1):13-18.

59. Yildiz E, Tosun G. Evaluation of formocresol, calcium hydroxide, ferric sulfate, and MTA primary molar pulpotomies. Eur J Dent 2014;8(2):234-240.

60. Durmus B, Tanboga I. In vivo evaluation of the treatment outcome of pulpotomy in primary molars using diode laser, formocresol, and ferric sulphate. Photomed Laser Surg 2014;32(5):289-295.

61. Olatosi OO, Sote EO, Orenuga OO. Effect of mineral trioxide aggregate and formocresol pulpotomy on vital primary teeth: a clinical and radiographic study. Niger J Clin Pract 2015;18(2):292-296.

62. Boller RJ. Reactions of pulpotomized teeth to zinc oxide and formocresol-type drugs. ASDC J Dent Child 1972;39(4): 298-307.

63. Garcia-Godoy F. A comparison between zinc oxide-eugenol and polycarboxylate cements on formocresol pulpotomies. The Journal of pedodontics 1982;6(3):203.

64. Loos P, Straffon L, Han S. Biological effects of formocresol. ASDC Journal of dentistry for children 1972;40(3):193-197.

65. Myers DR, Shoaf HK, Dirksen TR, Pashley DH, Whitford GM, Reynolds KE. Distribution of 14 C-formaldehyde after pulpotomy with formocresol. J Am Dent Assoc 1978;96(5): 805-813.

66. Pashley EL, Myers DR, Pashley DH, Whitford GM. Systemic distribution of $14 \mathrm{C}$-formaldehyde from formocresol-treated pulpotomy sites. J Dent Res 1980;59(3):602-608.

67. Rølling I, Lambjerg-Hansen H. Pulp condition of successfully formocresol-treated primary molars. European Journal of Oral Sciences 1978;86(4):267-272.

68. Pruhs RJ, Olen GA, Sharma PS. Relationship between formocresol pulpotomies on primary teeth and enamel defects on their permanent successors. The Journal of the American Dental Association 1977;94(4):698-700.

69. Rolling I, Poulsen S. Formocresol pulpotomy of primary teeth and occurrence of enamel defects on the permanent successors. Acta Odontol Scand 1978;36(4):243-247.

70. Bimstein E. Pulpotomy treatment in primary teeth. Compend Contin Educ Dent 1985;6(8):586-587, 590-581.

71. van Mullem PJ, Simon M, Lamers AC. Formocresol: a root canal disinfectant provoking allergic skin reactions in presensitized guinea pigs. J Endod 1983;9(1):25-29.

72. Rolling I, Thulin H. Allergy tests against formaldehyde, cresol, and eugenol in children with formocresol pulpotomized primary teeth. Scand J Dent Res 1976;84(5):345-347.
73. Hill SD, Berry CW, Seale NS, Kaga M. Comparison of antimicrobial and cytotoxic effects of glutaraldehyde and formocresol. Oral Surg Oral Med Oral Pathol 1991;71(1):89-95.

74. Teuscher GW, Zander HA. A preliminary report on pulpotomy. Northwestern Dental Res and Grad Quart University Bulletin 1938;39(4): 4-8.

75. Zander H. Reaction of the pulp to calcium hydroxide. Journal of Dental Research 1939;18(4):373-379.

76. Via WF Jr. Evaluation of deciduous molars treated by pulpotomy and calcium hydroxide. Journal of the American Dental Association 1955;50(1):34-41.

77. Magnusson B. Therapeutic pulpotomy in primary molarsclinical and histological follow-up. I. Calcium hydroxide paste as wound dressing. Odontol Revy 1970;21(4):415-431.

78. Schroder U, Granath LE. On internal dentine resorption in deciduous molars treated by pulpotomy and capped with calcium hydroxide. Odontol Revy 1971;22(2):179-188.

79. Schroder U. Effect of an extra-pulpal blood clot on healing following experimental pulpotomy and capping with calcium hydroxide. Odontol Revy 1973;24(3):257-268.

80. Schroder U, Granath LE. Early reaction of intact human teeth to calcium hydroxide following experimental pulpotomy and its significance to the development of hard tissue barrier. Odontol Revy 1971;22(4):379-395.

81. Schroder U, Granath LE. Scanning electron microscopy of hard tissue barrier following experimental pulpotomy of intact human teeth and capping with calcium hydroxide. Odontol Revy 1972;23(2):211-220.

82. Tronstad L, Mjor IA. Capping of the inflamed pulp. Oral Surg Oral Med Oral Pathol 1972;34(3):477-485.

83. Schröder U. Agreement between clinical and histologic findings in chronic coronal pulpitis in primary teeth. European Journal of Oral Sciences 1977;85(7):583-587.

84. Schroder U. A 2-year follow-up of primary molars, pulpotomized with a gentle technique and capped with calcium hydroxide. Scand J Dent Res 1978;86(4):273-278.

85. Cvek M. A clinical report on partial pulpotomy and capping with calcium hydroxide in permanent incisors with complicated crown fracture. Journal of Endodontics 1978;4(8): 232-237.

86. Holland R, de Souza V, de Mello W, Nery MJ, Bernabe PF, Otoboni Filho JA. Permeability of the hard tissue bridge formed after pulpotomy with calcium hydroxide: a histologic study. Journal of the American Dental Association 1979;99(3): 472-475.

87. Ozata F, Piskin B, Erdilek N, Aktener O, Tuncer AV. Comparison of calcium hydroxide and formocresol pulpotomies in primary teeth in lambs: preliminary study. Journal of Endodontics 1987;13(7):328-335.

88. Cvek M, Granath L, Cleaton-Jones P, Austin J. Hard tissue barrier formation in pulpotomized monkey teeth capped with cyanoacrylate or calcium hydroxide for 10 and 60 minutes. Journal of Dental Research 1987;66 (6):1166-1174.

89. Heide $S$. The effect of pulp capping and pulpotomy on hard tissue bridges of contaminated pulps. Int Endod J 1991; 24(3):126-134.

90. Heilig J, Yates J, Siskin M, McKnight J, Turner J. Calcium hydroxide pulpotomy for primary teeth: a clinical study. Journal of the American Dental Association 1984;108(5): 775-778.

91. Schroder U. Effects of calcium hydroxide-containing pulpcapping agents on pulp cell migration, proliferation, and 
differentiation. Journal Dental Research 1985;64 Spec no: 541-548.

92. s' Gravenmade E. Some biochemical considerations of fixation in endodontics. Journal of Endodontics 1975;1:233-237.

93. Russell AD, Hopwood D. The biological uses and importance of glutaraldehyde. Prog Med Chem 1976;13:271-301.

94. Ranly D, Lazzari E. A biochemical study of two bifunctional reagents as alternatives to formocresol. Journal of Dental Research 1983;62(10):1054-1057.

95. Ranly DM, Horn D, Zislis T. The effect of alternatives to formocresol on antigenicity of proteins. Journal of Dental Research 1985;64(10):1225-1228.

96. Dankert J, Wemes J. Diffusion of formocresol and glutaraldehyde through dentin and cementum. Journal of Endodontics 1976;2(2):42-46.

97. Rusmah M, Rahim Z. Diffusion of buffered glutaraldehyde and formocresol from pulpotomized primary teeth. ASDC journal of dentistry for children 1991;59(2):108-110.

98. Garcia-Godoy F. Clinical evaluation of glutaraldehyde pulpotomies in primary teeth. Acta Odontol Pediatr 1983;4(2): 41-44.

99. Fuks A, Bimstein E, Michaeli Y. Glutaraldehyde as a pulp dressing after pulpotomy in primary teeth of baboon monkeys. Pediatric Dentistry 1986;8(1):32-36.

100. Myers DR, Pashley DH, Lake FT, Burnham D, Kalathoor S, Waters R. Systemic absorption of 14 C-glutaraldehyde from glutaraldehyde-treated pulpotomy sites. Pediatric Dentistry 1986;8(3):134-138.

101. Garcia-Godoy F. A 42 month clinical evaluation of glutaraldehyde pulpotomies in primary teeth. The Journal of Pedodontics 1985;10(2):148-155.

102. Fuks A, Bimstein E, Klein H. Assessment of a $2 \%$ buffered glutaraldehyde solution in pulpotomized primary teeth of school children: a preliminary report. The Journal of Pedodontics 1985;10(4):323-330.

103. Fuks A, Bimstein E, Guelmann M, Klein H. Assessment of a $2 \%$ buffered glutaraldehyde solution in pulpotomized primary teeth of schoolchildren. ASDC journal of dentistry for children 1989;57(5):371-375.

104. Sun HW, Feigal RJ, Messer HH. Cytotoxicity of glutaraldehyde and formaldehyde in relation to time of exposure and concentration. Pediatric Dentistry 1990;12(5):303-307.

105. Tsai TP, Su HL, Tseng LH. Glutaraldehyde preparations and pulpotomy in primary molars. Oral Surg Oral Med Oral Pathol 1993;76(3):346-350.

106. Davis M, Myers R, Switkes M. Glutaraldehyde: an alternative to formocresol for vital pulp therapy. ASDC journal of dentistry for children 1981;49(3):176-180.

107. Kopel HM, BernickS, Zachrisson E, DeRomero SA. The effects of glutaraldehyde on primary pulp tissue following coronal amputation: an in vivo histologic study. ASDC journal of dentistry for children 1980;47(6):425-430.

108. Alacam A. Pulpal tissue changes following pulpotomies with formocresol, glutaraldehyde-calcium hydroxide, glutaraldehyde-zinc oxide eugenol pastes in primary teeth. The Journal of pedodontics 1988;13(2):123-132.

109. Rusmah M. Pulpal tissue reaction to buffered glutaraldehyde. The Journal of clinical pediatric dentistry 1991;16(2):101-106

110. Ranly DM, Garcia-Godoy F. Reviewing pulp treatment for primary teeth. Journal of the American Dental Association 1991;122(9):83-85.
111. Feigal R, Messer H. A critical look at glutaraldehyde. Pediatric Dentistry 1989;12(2):69-71.

112. Lloyd JM, Seale N, Wilson C. The effects of various concentrations and lengths of application of glutaraldehyde on monkey pulp tissue. Pediatric Dentistry 1988;10(2):115.

113. Laws A. Pulpotomy by electro-coagulation. NZ Dent J 1957;53:68

114. Yakuschii M. Pulpotomy of primary teeth by means of electrosurgery. Shoni Shikagaku Zasshi 1975;13:213-219.

115. Ruemping DR, Morton TH Jr, Anderson MW. Electrosurgical pulpotomy in primates - a comparison with formocresol pulpotomy. Pediatric Dentistry 1983;5(1):14-18.

116. Shulman ER, McIver F, Burkes E. Comparison of electrosurgery and formocresol as pulpotomy techniques in monkey primary teeth. Pediatric Dentistry 1987;9(3):189-194.

117. Sheller B, Morton T. Electrosurgical pulpotomy: A pilot study in humans. Journal of Endodontics 1987;13(2):69-76.

118. Mack RB. Dean JA. Electrosurgical pulpotomy: A retrospective human study. ASDC journal of dentistry for children 1993;60(2):107-114.

119. Oztas N, Ulusu T, Oygür T, Cokpekin F. Comparison of electrosurgery and formocresol as pulpotomy techniques in dog primary teeth. The Journal of clinical pediatric dentistry 1993;18(4):285-289.

120. Dean JA, Mack RB, Fulkerson BT, Sanders BJ. Comparison of electrosurgical and formocresol pulpotomy procedures in children. Int J Paediatr Dent 2002;12(3):177-182.

121. Fishman SA, Udin RD, Good DL, Rodef F. Success of electrofulguration pulpotomies covered by zinc oxide and eugenol or calcium hydroxide: a clinical study. Pediatric Dentistry 1996;18(5):385-390.

122. Shoji S, Nakamura M, Horiuchi H. Histopathological changes in dental pulps irradiated by $\mathrm{CO}_{2}$ laser: a preliminary report on laser pulpotomy. Journal of Endodontics 1985;11(9): 379 384.

123. Jukić S, Anić I, Koba K, Najžar-Fleger D, Matsumoto K. The effect of pulpotomy using $\mathrm{CO}_{2}$ and Nd:YAG lasers on dental pulp tissue. International endodontic journal 1997;30(3): 175-180.

124. Neena I, Poornima P, Edagunji G. Lasers in pediatric dentistry: A review. International Journal of Contemporary Dental and Medical Reviews 2015;2015. Article ID: 030115, 2015. doi: 10.15713/ins.ijcdmr.29

125. Cotes O, Boj J, Canalda C, Carreras M. Pulpal tissue reaction to formocresol vs ferric sulfate in pulpotomized rat teeth. The Journal of clinical pediatric dentistry 1996;21(3):247-253.

126. Loh A, O'Hoy P, Tran X, Charles R, Hughes A, Kubo K, et al. Evidence-based assessment: evaluation of the formocresol versus ferric sulfate primary molar pulpotomy. Pediatric Dentistry 2004;26 (5):401-409.

127. Yadav P, Indushekar K, Saraf B, Sheoran N, Sardana D. Comparative evaluation of Ferric Sulfate, Electrosurgical and Diode Laser on human primary molars pulpotomy: an 'in-vivo' study. Laser Ther 2014;23(1):41-47.

128. Fadavi S, Anderson A, Punwani I. Freeze-dried bone in pulpotomy procedures in monkey. The Journal of pedodontics 1988;13(2):108-122.

129. Nakashima M. The induction of reparative dentine in the amputated dental pulp of the dog by bone morphogenetic protein. Arch Oral Biol 1990;35(7):493-497. 
130. Rutherford RB, Wahle J, Tucker M, Rueger D, Charette M. Induction of reparative dentine formation in monkeys by recombinant human osteogenic protein-1. Arch Oral Biol 1993;38(7):571-576.

131. Seow WK, Thong Y. Evaluation of the novel anti-inflammatory agent tetrandrine as a pulpotomy medicament in a canine model. Pediatric Dentistry 1993;15(4):260-266.

132. Nevins AJ, LaPorta RF, Borden BG, Spangberg LS. Pulpotomy and partial pulpectomy procedures in monkey teeth using cross-linked collagen-calcium phosphate gel. Oral Surgery, Oral Medicine, Oral Pathology 1980;49(4):360-365.

133. Bimstein E, Shoshan S. Enhanced healing of tooth-pulp wounds in the dog by enriched collagen solution as a capping agent. Archives of Oral Biology 1981;26(2):97-101.

134. Fuks A, Michael Y, Sofer-saka B, Shosan S. Enriched collagen solution as a pulp dressing in pulpotomized teeth in monkeys. Pediatric Dentistry 1984;6(4):243-247.

135. Prabhu NT, Munshi AK. Clinical, radiographic and histological observations of the radicular pulp following 'feracrylum' pulpotomy. J Clin Pediatr Dent 1997;21(2):151-156.

136. Wilson AD, Kent BE. A new translucent cement for dentistry. The glass ionomer cement. Br Dent J 1972;132(4):133-135.

137. Wilson AD, McLean JW. Glass-ionomer cement. Quintessence Pub Co; 1988.

138. Croll TP, Killian CM. Class I and class II light-hardened glassionomer/resin restorations. Compendium 1993;14(7):908, 910-902, 914 passm; quiz 918.

139. Croll TP, Nicholson JW. Glass ionomer cements in pediatric dentistry: review of the literature. Pediatric Dentistry 2002;24 (5):423-429.

140. Hume WR, Mount GJ. In vitro studies on the potential for pulpal cytotoxicity of glass-ionomer cements. Journal of Dental Research 1988;67(6):915-918.

141. Felton DA, Cox CF, Odom M, Kanoy BE. Pulpal response to chemically cured and experimental light-cured glass ionomer cavity liners. J Prosthet Dent 1991;65(5):704-712.

142. Torabinejad M, Hong CU, McDonald F, Pitt Ford TR. Physical and chemical properties of a new root-end filling material. Journal of Endodontics 1995;21(7):349-353.

143. Parirokh $\mathrm{M}$, Torabinejad $\mathrm{M}$. Mineral trioxide aggregate: a comprehensive literature review: part III: clinical applications, drawbacks, and mechanism of action. Journal of Endodontics 2010;36(3):400-413.

144. Anthonappa R, King N, Martens L. Is there sufficient evidence to support the long-term efficacy of mineral trioxide aggregate (MTA) for endodontic therapy in primary teeth? International endodontic journal 2013;46(3):198-204.

145. Chakraborty A. Will Portland cement be a cheaper alternative to mineral trioxide aggregate in clinical use? a comprehensive review of literature. International Journal of Contemporary Dental and Medical Reviews 2015;2015. Article ID: 110215, 2015. doi: 10.15713/ins.ijcdmr.69

146. Eidelman E, Holan G, Fuks A. Mineral trioxide aggregate vs formocresol in pulpotomized primary molars: a preliminary report. Pediatric Dentistry 2000;23(1):15-18.

147. Sonmez D, Sari S, Cetinbas T. A Comparison of four pulpotomy techniques in primary molars: a long-term follow-up. Journal of Endodontics 2008;34(8):950-955.

148. Maroto M, Barberia E, Vera V, Garcia-Godoy F. Mineral trioxide aggregate as pulp dressing agent in pulpotomy treatment of primary molars: 42-month clinical study. American Journal of Dentistry 2007;20(5):283.
149. Kalaskar RR, Damle SG. Comparative evaluation of lyophilized freeze dried platelet derived preparation with calcium hydroxide as pulpotomy agents in primary molars. J Indian Soc Pedod Prev Dent 2004;22(1):24-29.

150. Sabbarini J, Mounir M, Dean J. Histological evaluation of enamel matrix derivative as a pulpotomy agent in primary teeth. Pediatric Dentistry 2007;29(6):475-479.

151. Sabbarini J, Mohamed A, Wahba N, El-Meligy O, Dean J. Comparison of enamel matrix derivative versus formocresol as pulpotomy agents in the primary dentition. Journal of Endodontics 2008;34(3):284-287.

152. Vargas KG, Packham B, Lowman D. Preliminary evaluation of sodium hypochlorite for pulpotomies in primary molars. Pediatric Dentistry 2006;28(6):511-517.

153. Vostatek SF, Kanellis MJ, Weber-Gasparoni K, Gregorsok RL. Sodium hypochlorite pulpotomies in primary teeth: a retrospective assessment. Pediatric Dentistry 2011;33(4): 327-332.

154. Al-Mutairi MA, Bawazir OA. Sodium hypochlorite versus Formocresol in primary molars pulpotomies: a randomized clinical trial. Eur J Paediatr Dent 2013;14(1):33-36.

155. Shabzendedar M, Mazhari F, Alami M, Talebi M. Sodium hypochlorite vs formocresol as pulpotomy medicaments in primary molars: 1-year follow-up. Pediatric Dentistry 2013; 35(4):329-332.

156. Ruby JD, Cox CF, Mitchell SC, Makhija S, Chompu-Inwai P, Jackson J. A randomized study of sodium hypochlorite versus formocresol pulpotomy in primary molar teeth. Int J Paediatr Dent 2013;23(2):145-152.

157. Akcay M, Sari S. The effect of sodium hypochlorite application on the success of calcium hydroxide and mineral trioxide aggregate pulpotomies in primary teeth. Pediatric Dentistry 2014;36(4):316-321.

158. Conti TR, Sakai VT, Fornetti AP, Moretti AB, Oliveira TM, Lourenco Neto N, et al. Pulpotomies with Portland cement in human primary molars. J Appl Oral Sci 2009;17(1):66-69.

159. Sakai VT, Moretti AB, Oliveira TM, Fornetti AP, Santos CF, Machado MA, et al. Pulpotomy of human primary molars with MTA and Portland cement: a randomised controlled trial. Br Dent J 2009;207(3):E5; discussion 128-129.

160. Steffen R, Van Waes H. Understanding mineral trioxide aggregate/Portland cement: a review of literature and background factors. European Archives of Paediatric Dentistry 2009;10(2):93-97.

161. Shayegan A, Atash R, Petein M, Abbeele AV. Nanohydroxyapatite used as a pulpotomy and direct pulp capping agent in primary pig teeth. ASDC journal of dentistry for children 2010;77(2):77-83.

162. Malekafzali B, Shekarchi F, Asgary S. Treatment outcomes of pulpotomy in primary molars using two endodontic biomaterials. A 2-year randomised clinical trial. European journal of paediatric dentistry: official journal of European Academy of Paediatric Dentistry 2011;12(3):189-193.

163. Jose B, Ratnakumari N, Mohanty M, Varma H, Komath M. Calcium phosphate cement as an alternative for formocresol in primary teeth pulpotomies. Indian Journal of Dental Research 2013;24(4):522.

164. Mohammad SG, Raheel SA, Baroudi K. Clinical and Radiographic Evaluation of Allium sativum oil as a new medicament for vital pulp treatment of primary teeth. Journal of International Oral Health 2014;6(6). 